\title{
Early Cenozoic tropical climate: report from the Tanzania Onshore Paleogene Integrated Coring (TOPIC) workshop
}

\author{
P. N. Pearson ${ }^{1}$ and W. Hudson ${ }^{2}$ \\ ${ }^{1}$ School of Earth and Ocean Sciences, Cardiff University, Main Building, Park Place, Cardiff CF10 3AT, UK \\ ${ }^{2}$ Tanzania Petroleum Development Corporation, Lumumba Street, Dar-es-Salaam, Tanzania
}

Correspondence to: P. N. Pearson (pearsonp@ cardiff.ac.uk)

Received: 30 September 2014 - Revised: 13 November 2014 - Accepted: 24 November 2014

- Published: 22 December 2014

\begin{abstract}
We are currently developing a proposal for a new International Continental Scientific Drilling Program (ICDP) project to recover a stratigraphic and paleoclimatic record from the full succession of Eocene hemipelagic sediments that are now exposed on land in southern Tanzania. Funding for a workshop was provided by ICDP, and the project was advertised in the normal way. A group of about 30 delegates assembled in Dar-es-Salaam for 3 intensive days of discussion, project development, and proposal writing. The event was hosted by the Tanzania Petroleum Development Corporation (TPDC) and was attended by several geologists, geochemists, geophysicists, and micropaleontologists from TPDC and the University of Dar-es-Salaam. International delegates were from Canada, Germany, India, Ireland, Italy, the Netherlands, United Kingdom, and United States (and we also have project partners from Australia, Belgium, and Sweden who were not able to attend). Some of the scientists are veterans of previous scientific drilling in the area, but over half are new on the scene, mostly having been attracted by Tanzania's reputation for world-class paleoclimate archives. Here we outline the broad aims of the proposed drilling and give a flavor of the discussions and the way our proposal developed during the workshop. A video of the workshop with an introduction to the scientific goals and interviews of many of the participants is available at http://vimeo.com/107911777.
\end{abstract}

\section{Scientific rationale}

The current atmospheric $\mathrm{CO}_{2}$ concentration (about $400 \mathrm{ppm}$ ) is similar to that of the Pliocene, and in the coming century we may see levels comparable to those of the early Paleogene (IPCC, 2013). As the planet begins to be affected by anthropogenic greenhouse gas emissions, it is important to understand climate forcing and response in Earth's past, especially greenhouse episodes. In particular we need to know

- to what extent atmospheric $\mathrm{CO}_{2}$ and global temperature co-varied during previous intervals of global warmth.

- how extreme climatic conditions were in the tropics, both in the ocean and on land.

- what the response was of the marine and terrestrial biota to extreme climate states and intervals of climate change.
- whether the paleoclimate forcings and responses we infer from the sediment record are consistent with the predictions of general circulation models (GCMs)?

The hemipelagic tropical marine clays of the Kilwa Group, now uplifted and exposed onshore Tanzania (Fig. 1), are uniquely placed to help answer these questions because of their extraordinary potential for climate proxy work including temperature and $p \mathrm{CO}_{2}$ proxies (e.g., Pearson et al., 2007, 2009). Carbonate microfossils (foraminifera and nannofossils) are extremely well preserved through the entire Paleogene (Pearson et al., 2001, 2007; Wade and Pearson, 2008; Bown et al., 2008) (Fig. 2). Oxygen isotope ratios of planktonic foraminifera have been widely used to estimate sea surface temperatures in the past, but in deep-sea carbonates they are usually diagenetically altered, resulting in an artificially high oxygen isotope signal (i.e., low temperature), thereby biasing temperature reconstructions. This is the primary rea- 


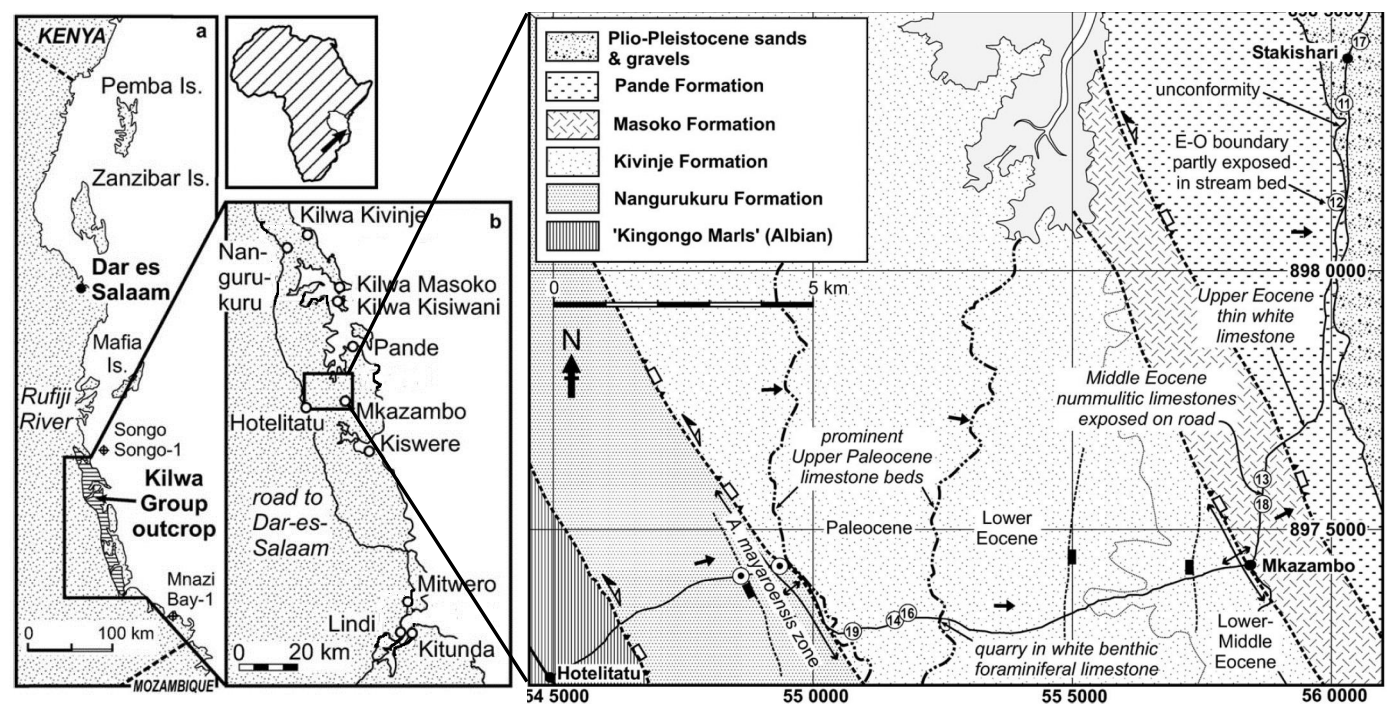

Figure 1. Location map. (a) Coastal Tanzania; (b) detail of Kilwa Group outcrop; (c) geological map showing principal faults and sites of several Tanzania Drilling Project drill cores (circled numbers). The proposed TOPIC drill site is at TDP site 12 as highlighted by the circle in the northeastern corner of the geological map. Note: the Pande through Nangurukuru formations comprise the Kilwa Group. Modified from Nicholas et al. (2006).

son why deep-sea drilling has so far not been able to provide a consistent tropical paleotemperature record for the Eocene; hence it is central to our plan for Tanzania. The development of a calcareous microfossil "Konservat-Lagerstätte" onshore and offshore Tanzania appears to be related to clayrich sediments that act as a relatively impermeable medium, isolating microfossils from chemical and physical processes of diagenetic alteration (Pearson et al., 2001; Bown et al., 2008). The Tanzania hemipelagic sediments also contain exceptionally well-preserved organic matter, including terrestrial pollen and spores, marine dinoflagellate cysts (Pearson et al., 2004), and organic biomarkers (Van Dongen et al., 2006), suitable for reconstructions of both marine and terrestrial environments.

The Tanzania Onshore Paleogene Integrated Coring (TOPIC) consortium plans to core the entire Eocene succession (from about 56 to 33 million years ago) at one site. The Eocene epoch was characterized by globally warm climate states and a series of climate perturbations and trends. These include the Paleocene-Eocene thermal maximum, several other short hyperthermal events, the extended super-warm phase known as the Early Eocene Climate Optimum, and the long-term global cooling that eventually led to the EoceneOligocene transition and the development of a continentalscale ice cap on Antarctica. This rich history of climatic change provides us with a wide range of questions to address. Understanding climate change in Earth's past is societally important and well aligned to ICDP's science plan.

The planned drilling will produce a standard reference section for Eocene stratigraphic correlation, including highresolution magneto- and cyclostratigraphy and integrated

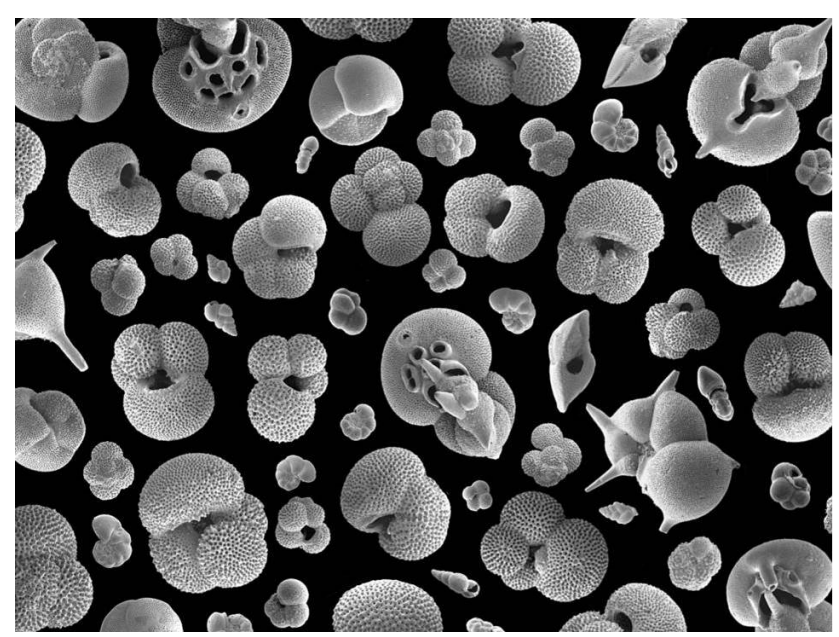

Figure 2. Planktonic foraminifera from the Eocene-Oligocene transition at the proposed drill site. The exquisite preservation is typical of the Tanzanian Kilwa Group and allows for high-quality biostratigraphy as well as reliable geochemical proxy work including oxygen isotope paleotemperatures and boron isotope palaeo$p \mathrm{CO}_{2}$ estimation. Organic biomarkers are also extremely well preserved.

biostratigraphy using calcareous and organic microfossils. The detailed stratigraphic framework and information on basin evolution will be of great interest regarding hydrocarbon exploration in Tanzania, which hosts major gas fields offshore in Eocene age reservoirs. The drill site also provides an exceptionally interesting opportunity to study the biomass and activity of the deep biosphere in a homogeneous clayrich formation down to a depth of $1000 \mathrm{~m}$. 


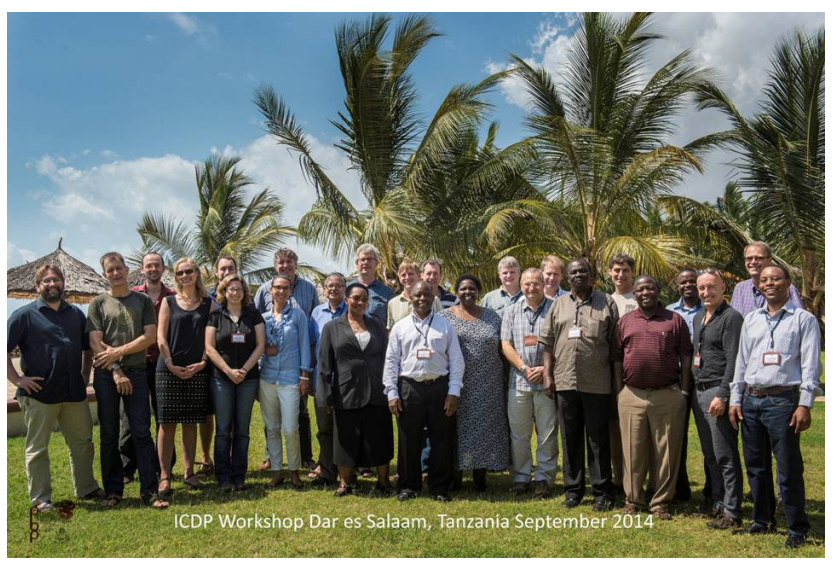

Figure 3. The workshop participants. Photo: Ishka Michoka, Plastic Buddha Productions.

\section{The workshop}

The workshop was held from 9 to 11 September at a hotel on the outskirts of Dar-es-Salaam (Fig. 3).

The meeting was preceded by some informal discussions with potential drilling contractors to establish the capacity and availability of potential drill rigs and consider various logistical aspects. This helped us to clarify the likely rate of progress and cost of operations. The drilling itself is relatively straightforward for an ICDP project (continuous coring to a depth of about $1000 \mathrm{~m}$ in two holes), but the site is fairly remote, so operations will need to be completed within the long dry season. A plentiful supply of freshwater is one of the more significant challenges and would require on-site storage and frequent trucking. Seawater would be much easier to source, and delegates at the workshop highlighted the potential benefits of using seawater, especially for easy detection of possible contamination of pore waters by drilling fluid, which is an important concern for the microbiological objectives.

The first day was largely devoted to a series of presentations setting out the main scientific themes in the context of past work, most notably the Tanzania Drilling Project (funded by successive research grants from the UK Natural Environment Research Council and US National Science Foundation). This program ran from 2002 to 2009, during which time a total of 40 shallow drill sites were cored to a maximum depth of about $150 \mathrm{~m}$ using small truck-mounted rigs. This drilling has produced over 40 peer-reviewed papers to date but also has a series of limitations inherent in the technology, including relatively low maximum penetration depth, unexceptional recovery and core quality, narrow diameter cores, and no downhole logging. Only about half the total stratigraphy was recovered despite these intensive efforts; hence the need for deeper penetration and a much more continuous record via ICDP is very clear.
Links to IODP Full Proposal 778 (Tanzania Offshore Paleoclimate; TOP) were discussed. That project has similar and complementary aims but with a greater focus on the Neogene, which is only poorly represented onshore. Together IODP-TOP and ICDP-TOPIC will produce an onshoreoffshore transect and recovery of almost the entire Cenozoic (from the Holocene down to the top Paleocene). IODP-TOP has been graded as "excellent" by the IODP Proposal Evaluation Panel but has so far not been scheduled because of perceived piracy risk, although this has diminished greatly in recent years; hence we are optimistic that it will be available for scheduling soon. We note that successful completion of ICDP-TOPIC would allow IODP-TOP to reduce the proposed deep drilling at one site without compromising its scientific objectives, and so allow more ship time for triple coring and drilling of an alternative site.

One area of science that is new to the proposal at this stage is the study of the deep subsurface biosphere. The TOPIC project provides an exceptionally interesting opportunity to study prokaryotic activity and biomass in a homogeneous clay-rich environment down to a depth of $1 \mathrm{~km}$. Clay-rich sediments occur over large areas and are attractive targets for subsurface waste disposal, including nuclear waste, but knowledge of prokaryotic activity in such environments is very limited (Parkes et al., 2014). The Kilwa Group sediments have exceptional preservation of micro- and nannofossils, indicating limited diagenesis and pore fluid activity, which in turn suggests that prokaryotic activity and populations may be much more limited than in other sediment types at similar depths. It has been suggested that subsurface bacteria require interconnected pore throats greater than $0.2 \mu \mathrm{m}$ in diameter for sustained activity (Fredrickson et al., 1997). If that is so, then in Tanzania the prokaryotes may be "entombed" in the clays and therefore more representative of the original marine sedimented population than more active subsurface populations. Hence the proposed drilling will help us answer some fundamental unknowns in the field.

Other scientific areas discussed include the challenges of modeling Eocene climate, linkages between continental and marine climate, fundamental questions of controls on evolution and ecology in a changing environment, and what we may be able to learn in this location about the late Eocene impact events. Having refined our scientific aims, we then moved on to develop details of the sampling strategy for the full range of analyses and proxies and a collaboration plan to ensure those aims can be realized.

Also of importance is how to maximize the benefit for Tanzania. The country is experiencing a boom in exploration thanks to recent large gas discoveries offshore. Knowledge of the Eocene stratigraphy and environments and basin evolution will be important in the search for new discoveries. To help build scientific capacity in the area, the University of Dar-es-Salaam is currently initiating a master's level degree program with an emphasis on petroleum geology. The TOPIC project will provide a major opportunity for students 


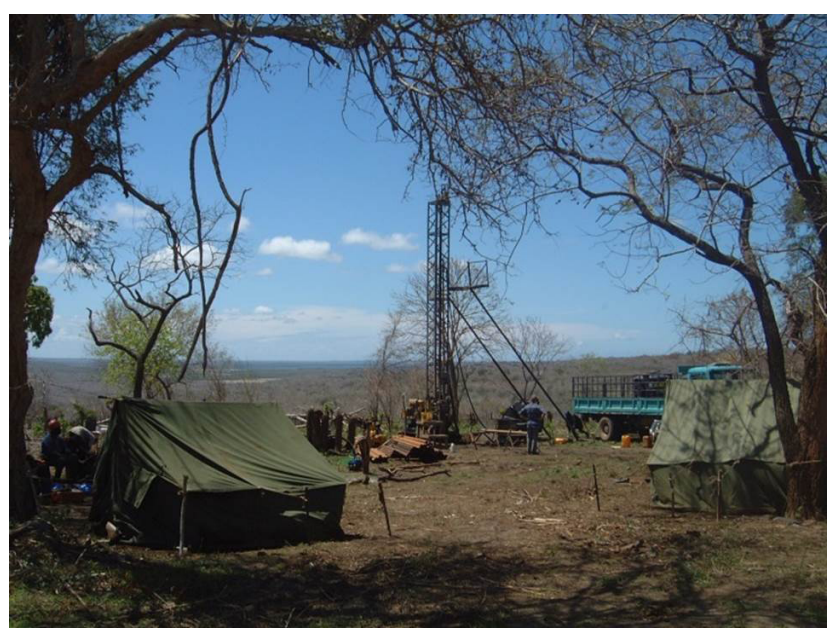

Figure 4. One of 40 shallow penetration boreholes drilled by the Tanzania Drilling Project (2002-2009). This is TDP site 12, the proposed TOPIC drill site (see Fig. 1 for location).

to engage with a cutting-edge science project and international scientists from many countries. We discussed ways of funding master's projects and involving students on site, possibly with an ICDP training course.

It is also important to engage with the public across Tanzania and in the area of drilling. Tanzania has experienced unprecedented extremes of weather recently that have been linked to climate change, and there is a growing awareness of the need to protect the natural environment. The goals and strategy of a national outreach program were discussed, including interaction with government science agencies, universities, and schools. The drilling will be an opportunity to inspire future Earth scientists and raise awareness of problems associated with climate change.

\section{Scope of the proposed drilling}

Days 2 and 3 of the workshop were focused on intensive discussions on the optimum location for the drill site (which will be near a previous Tanzania Drilling Project site - Fig. 4), scope of the proposed drilling, sampling requirements, and collaborative development of the full proposal. Progress was accelerated via a series of breakout groups tackling issues as disparate as education and outreach, recording the continental climate signal, organic geochemistry, biotic evolution, seismic interpretation, and operational logistics. Delegates contributed to a growing communal draft full proposal.

With reference to our feedback from ICDP, delegates were reminded not to feel overly constrained by the focus presented in the workshop proposal and that there was scope for expanding the scientific aims if desirable. In particular, and in response to the review comments, considerable discussion focused on the possibility of drilling deeper or adding a second site lower in the stratigraphy. The desirability of ob- taining a Cretaceous-Paleogene boundary was discussed, as well as significant deeper targets such as the CenomanianTuronian boundary interval. However in the end a consensus was reached that, given current knowledge and seismic information, the proposal should for now focus on a single site to recover the entire Eocene more or less as originally envisaged. A follow-on proposal or industry support may allow the project to develop further into the deeper objectives when better seismic data become available.

The available seismic data for the proposed Eocene drill site were discussed, and consideration was given to moving the location along strike to coincide exactly with a seismic line. The deep structure is relatively simple with a gentle ocean-ward dip. The risk of encountering hydrocarbon pockets at the proposed depths and location of drilling is considered low.

Our plan is to accomplish all the drilling within the 10 weeks of the long dry season in the area. Rates of likely drilling progress mean we can expect to drill two holes to approximately $1000 \mathrm{~m}$, which will enable penetration from the lower Oligocene to upper Paleocene. We will use the maximum possible diameter of pipe to allow maximum core recovery. Two holes will be drilled to fill in coring gaps in a composite section and to increase the material available for destructive sampling. On-site biostratigraphy in real time will allow us to monitor the rate of drilling progress and help determine the optimum point for termination of drilling. Sampling for deep biosphere and pore fluid geochemistry will also be done on site, as will basic core description, and cores will be scanned by a multi-sensor core logger. Cores in plastic liners will then be shipped to a suitable core laboratory and repository for intensive sampling.

\section{Project development}

Delegates left the workshop with a clear understanding of the aims of the drilling and the current extent of collaboration. Each participating country will now develop its own research plan within the context of the project as a whole. It now remains for us to finish the full proposal, including an operations plan, responsibility matrix, and detailed costings. In summary, the TOPIC project has enormous scientific potential and is relatively straightforward from a logistical perspective; hence we plan to have a full proposal submitted to ICDP within 4 months of the workshop. More details of the project are available at http://www.icdp-online.org/projects/ world/africa/tanzania/.

Acknowledgements. We thank ICDP for financial support for this workshop and the Tanzania Petroleum Development Corporation for helping to organize it. We thank Carlota Escutia and Bridget Wade for reviews.

Edited by: G. Camoin

Reviewed by: C. Escutia and B. S. Wade 


\section{References}

Bown, P. R., Dunkley Jones, T., Lees, J. A., Randell, R., Mizzi, J., Pearson, P. N., Coxall, H. K., Nicholas, C. J., Karega, A., Singano, J., and Wade, B. S.: A Paleogene calcareous microfossil Konservat-Lagerstätte from the Kilwa Group of coastal Tanzania, GSA Bulletin, 120, 3-12, doi:10.1130/B26261.1, 2008.

Fredrickson, J. K., McKinley, J. P., Bjornstad, B. N., Long, P. E., Ringelberg, D. B., White, D. C., Krumholz, L. R., Sulfita, J. M., Colwell, F. S., Lehman, R. M., Phelps, T. J., and Onstott, T. C.: Pore-size constraints on the activity and survival of subsurface bacteria in a late Cretaceous shale-sandstone sequence, northwestern New Mexico, Geomicrobiol. J., 14, 183-202, 1997.

IPCC: Climate Change 2013: The Physical Science Basis. Contribution of Working Group I to the Fifth Assessment Report of the Intergovernmental Panel on Climate Change, edited by: Stocker, T. F., Qin, D., Plattner, G.-K., Tignor, M., Allen, S. K., Boschung, J., Nauela, A., Xia, Y., Bex, V., and Midgley, P. M., Cambridge University Press, Cambridge, 1535 pp., 2013.

Nicholas, C. J., Pearson, P. N., Bown, P. R., Jones, T. D., Huber, B. T., Karega, A., Lees, J. A., McMillan, I. K., O'Halloran, A., Singano, J. M., and Wade, B. S.: Stratigraphy and sedimentology of the Upper Cretaceous to Paleogene Kilwa Group, southern coastal Tanzania, J. Afr. Earth Sci., 45, 431-466, 2006.

Parkes, R. J., Cragg, B., Roussel, E., Webster, G., Weightman, A., and Sass, H.: A review of prokaryotic populations and processes in sub-seafloor sediments, including biosphere:geosphere interactions, Mar. Geol., 352, 409-425, 2014.
Pearson, P. N., Ditchfield, P. W., Singano, J. M., Harcourt-Brown, K. G., Nicholas, C. J., Olsson, R. K., Shackleton, N. J., and Hall, M. A.: Warm tropical sea surface temperatures in the Late Cretaceous and Eocene epochs, Nature, 413, 481-487, 2001.

Pearson, P. N., Nicholas, C. J., Singano, J. M., Bown, P. R., Coxall, H. K., van Dongen, B. E., Huber, B. T., Karega, A., Lees, J. A., Msaky, E., Pancost, R. D., Pearson, M., and Roberts, A. P.: Paleogene and Cretaceous sediment cores from the Kilwa and Lindi areas of coastal Tanzania: Tanzania Drilling Project Sites 1-5, J. Afr. Earth Sci., 39, 25-62, 2004.

Pearson, P. N., van Dongen, B. E., Nicholas, C. J., Pancost, R. D., Schouten, S., Singano, J. M., and Wade, B. S.: Stable warm tropical climate through the Eocene epoch, Geology, 35, 211-214, 2007.

Pearson, P. N., Foster, G. L., and Wade, B. S.: Atmospheric carbon dioxide through the Eocene/Oligocene climate transition, Nature, 461, 1110-1113, 2009.

Van Dongen, B. E., Talbot, H. M., Schouten, S., Pearson, P. N., and Pancost, R. D.: Well-preserved Cretaceous and Paleogene biomarkers from the Kilwa area, Tanzania, Org. Geochem., 37, 539-557, 2006.

Wade, B. S. and Pearson, P. N.: Planktonic foraminiferal turnover, diversity fluctuations and geochemical signals across the Eocene/Oligocene boundary in Tanzania, Mar. Micropaleontol. 68, 244-255, 2008. 